\title{
Спелеотемы пещеры Лунная (Средняя Азия)
}

\section{Базарова Е.П.}

Институт земной коры СО РАН, Иркутск, bazarova@crust.irk.ru

Аннотация. Приводятся первые сведения о вторичных минеральных образования пещеры Лунная, расположенной в юго-западной части Гиссарского хребта (Средняя Азия). Спелеотемы данной пещеры представлены агрегатами от гравитационных до кораллитовых кор. Широко распространен пещерный жемчуг, что указывает на существование обильных водотоков в пещере. Это, в свою очередь, указывает на более влажные климатические условия в данном районе в прошлом.

Ключевые слова: пещеры, спелеотемы, Средняя Азия

\section{Speleothems of the Lunnaya Cave (Central Asia)}

\section{Bazarova E.P.}

Institute of the Earth's Crust SB RAS, Irkutsk, bazarova@crust.irk.ru

Abstract. The article provides the first data on the secondary mineral formations of the Lunnaya Cave. This cave is located in the southwestern part of the Gissar Ridge (Central Asia). The speleothems of this cave are represented by aggregates from gravitational to corallite crusts. The widespread distribution of cave pearls indicates the increased water content in the cave in the past. This fact, in turn, indicates more humid climatic conditions in this region in the past.

Key words: caves, speleothems, Central Asia.

\section{Введение}

Пещеры Средней Азии активно исследуются экспедициями Екатеринбургского городского клуба спелеологов (СГС), начиная с 80-х годов XX века. Высокогорный карстовый район, расположенный в пределах юго-западных отрогов Гиссарского хребта - хребтов Байсунтау и Сурхан-
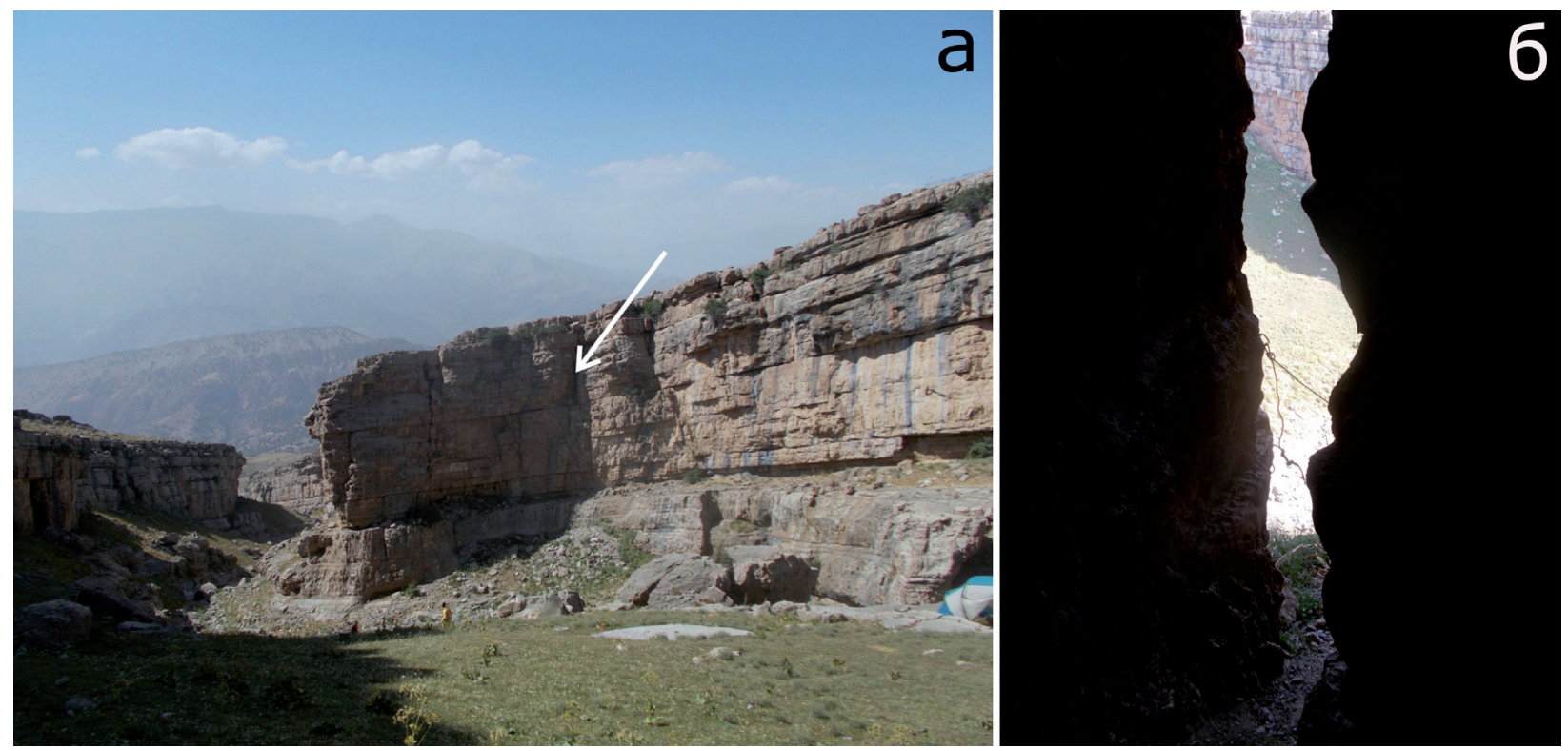

Рис. 1. Расположение п. Лунная и вид привходовой части.

a - каньон, вскрывающий вход в п. Лунная (расположение входа показано стрелкой), б - характерное сечение хода (вид изнутри пещеры).

Fig. 1. The location of the Lunnaya Cave and the view of the entrance part.

$\mathrm{a}$ - the canyon opening the entrance to the Lunnaya Cave (the location of the entrance is shown by an arrow), b - a characteristic section of the cave passage (view from the cave). 


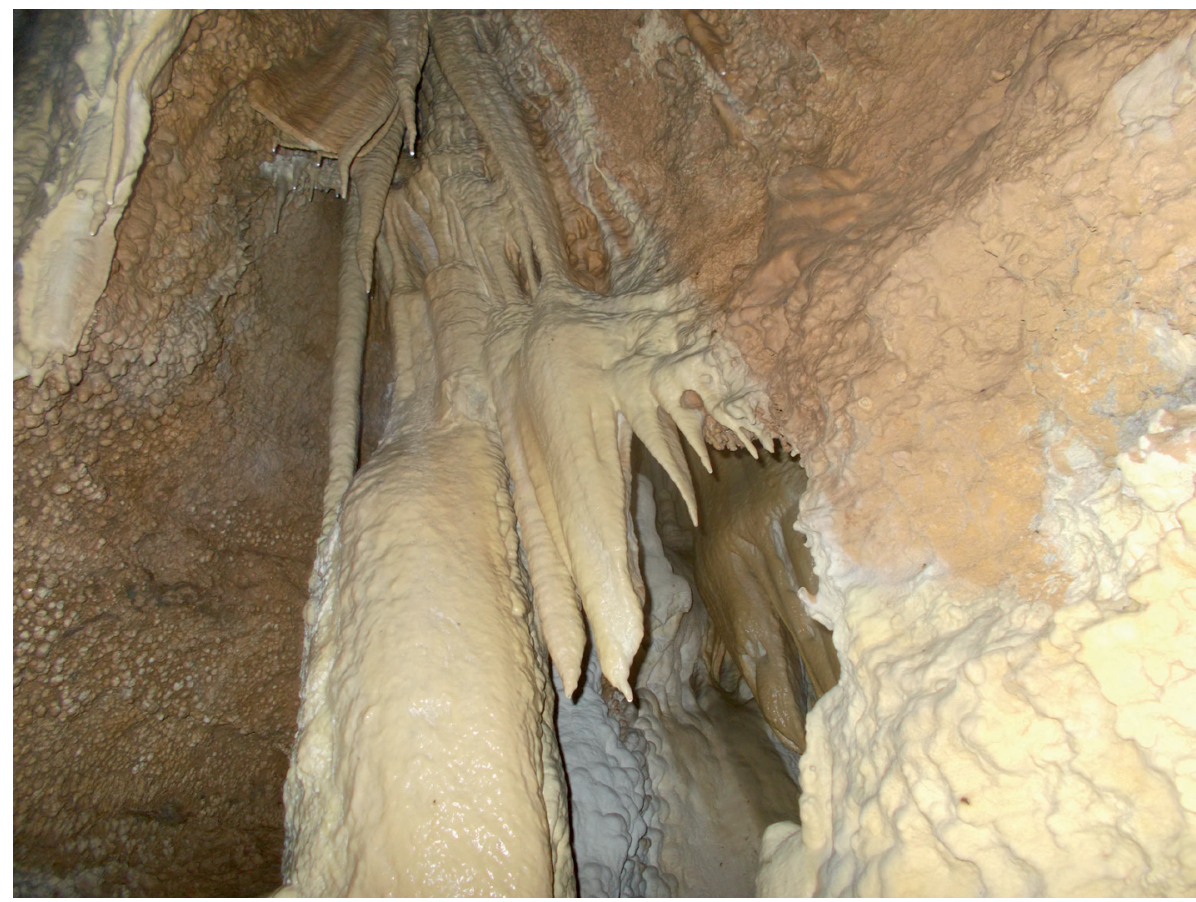

Рис. 2. Водные хемогенные образования пещеры Лунной: сталактиты, драпировки, натечные коры, мелкие кораллиты.

Fig. 2. Water chemogenic formations of the Lunnaya Cave: stalactites, draperies, flowstone, small corallites.

тау - является перспективным для открытия новых глубоких пещер по причине большого перепада высот (около 2 км) между входами в карстовые системы и источниками, в которых происходит разгрузка воды.

Несмотря на достаточно длительную историю исследования (Tsurichin et al., 2013), геологии и вторичной минералогии данных пещер уделялось мало внимания. Целью данной работы является краткая характеристика вторичных минеральных образований пещеры Лунная.

\section{Общие сведения о пещере}

Пещера Лунная находится на хребте Сурхантау. Вход расположен в вертикальной стене широкого каньона (рис. 1 а). Карстовая полость заложена в известняках верхней юры и представляет собой узкий высокий ход шириной 0.2-1 м с двумя небольшими гротами (рис. 1 б). Общая протяженность пещеры на сегодняшний день составляет 547 м при глубине 120 м по данным Екатеринбургского городского клуба спелеологов (СГС).

В пещере можно отметить пять типов вторичных образований в соответствии с генетическими типами по классификации Д.С. Соколова и Г.А. Максимовича (Максимович, 1963): остаточные (элювиальная или пещерная глина), обвальные (обломочные продукты обрушения сводов пещеры), водные механические осадки (отложения пещерных ручьев), водные хемогенные отложения (рис. 2) и органогенные (растительные остатки, множество гуано птиц и костей грызунов в привходовой части).

\section{Материалы и методы}

Отбор проб осуществлялся автором работы в ходе междугородной исследовательской экспедиции 2019 г (руководитель экспедиции Логинов В.Л.). Были взяты образцы водных хемогенных отложений, сломавшиеся естественным путем. Определение минерального состава образцов проводили в Геологическом институте СО РАН в г. Улан-Удэ на электронном сканирующем микроскопе "LEO-1430VP" (Carl Zeiss International) с энергодисперсионным спектрометром "INCAEnergy 350" (OxfordInstruments Analytical Ltd.) аналитиком Е.А. Хромовой. 


\section{Результаты и обсуждение}

В соответствии с классификацией, основанной на способе подачи активного раствора (Степанов, 1971; Мальцев, 1993), водные хемогенные образования в п. Лунной относятся к классам гравитационных (сталактиты, сталагмиты, драпировки), субаквальных (инкрустации дна водоемов) и кораллитовых кор (кораллиты) (рис. 2). К переходным формам между гравитационными и субаквальными корами следует относить гуры и пещерный жемчуг (пизолиты), распространенные в небольших гротах. Встречаются также геликтиты и мондмильх. Все перечисленные спелеотемы сложены кальцитом.

Наибольший интерес среди водных хемогенных образований в п. Лунной представляют такие редкие пещерные образования, как пещерный жемчуг. Пещерные жемчужины, в большом количестве (десятки в каждом гроте) находящиеся в гуровых ванночках размером 10-20 см и более при глубине до 3 см, имеют вытянутую уплощенную или сферическую форму, размеры их изменяются от 0.5 до 4 см. Отмечаются как гладкие пизолиты, так и ежевидные (покрытые кристаллами кальцита до 1 мм), а также образования с гладкой верхней и ежевидной нижней поверхностью. Затравки сложены мелкими частицами ильменита, мусковита, рутила, эпидота и многочисленными зернами кварца, сцементированными кальцитом, вышележащие слои сложены чистым кальцитом (рис. 3). Различий в химическом составе центральных (кроме затравки) и краевых участков жемчужин не наблюдается.

Судя по обилию натечных образований, в том числе гуров, в истории пещеры был период достаточно сильной обводненности, когда по стенам и полу пещеры шли потоки воды. Когда потоки сменились капелью, в мелких водоемах началось формирование пизолитов (Hill, Forti, 1997).

Однородный состав слоев жемчужин указывает на постоянный состав питающего раствора. Присутствие поблизости друг от друга жемчужин с гладкой и ежевидной поверхностью, повидимому, говорит об изменениях водопритока: при более активной капели формировались гладкие пизолиты, а в спокойных условиях на поверхности пизолитов формировались мелкие кристаллы кальцита.
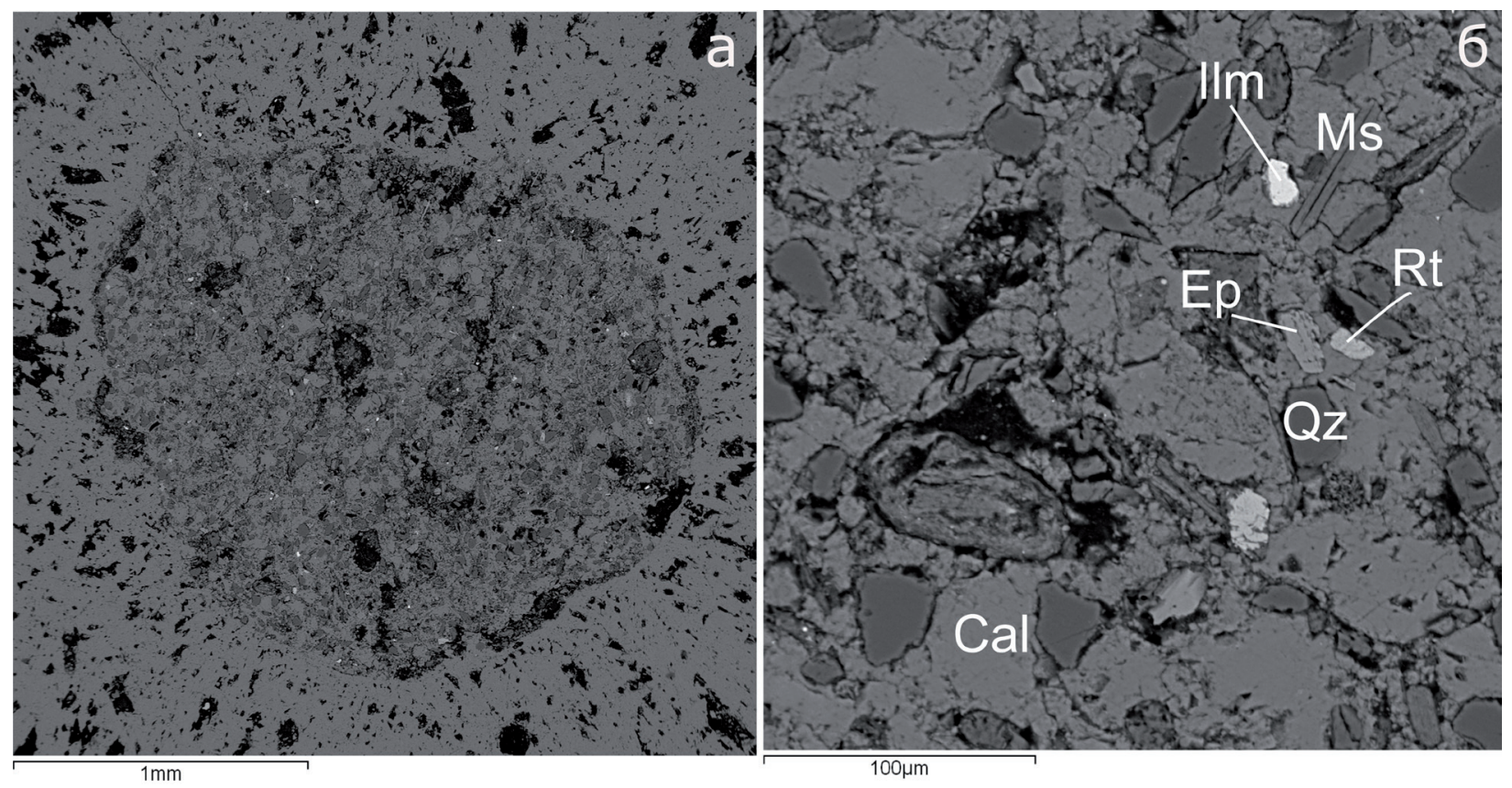

Рис. 3. Внутреннее строение пещерной жемчужины.

a - общий вид затравки и концентрических слоев кальцита вокруг, б - минеральные частицы, слагающие затравку. Ilm - ильменит, Ms - мусковит, Ep - эпидот, Rt - рутил, Qz - кварц, $\mathrm{Cal}$ - кальцит.

Fig. 3. The internal structure of the cave pearl.

$\mathrm{a}$ - general view of the core and concentric layers of calcite around, $\mathrm{b}$ - mineral particles composing the core. $\mathrm{Ilm}$ - ilmenite, Ms - muscovite, Ep - epidote, Rt - rutile, Qz - quartz, Cal - calcite. 
В настоящее время активные водотоки в пещере отсутствуют, наблюдаются только небольшие лужи на полу. В будущем планируются изотопные исследования и датирование слоев кальцита в пещерных жемчужинах, которые могут дать информацию об источнике воды и времени повышенной обводненности пещеры. Эти сведения, в свою очередь, несут информацию о палеоклимате на данной территории Средней Азии.

\section{Литература}

1. Максимович Г. А. Основы карстоведения. Т. 1. Пермь. 1963. 445 с.

2. Мальцев B.А. Минералы системы карстовых пещер Кап-Кутан (юго-восток Туркменистана) // Мир Камня (World of Stones). 1993. № 2. http://geo.web.ru/maltsev/liter_ws_r.html.

3. Степанов В.И. Периодичность процессов кристаллизации в карстовых пещерах / Труды минералогического музея им. Ферсмана. Вып. 20. Москва. 1971. С. 161-171.

4. Hill C.A., Forti P. Cave minerals of the world, 2nd ed. Huntsville. AL: National Speleological Society. 1997. 463 p.

5. Tsurikhin E., Loginov V., Sauro S., Breitenbach S. Exploration of high altitude caves in the Baisun-Tau mountain range, Uzbekistan // Proceedings of the $16^{\text {th }}$ International Congress of Speleology, July 21-28, Brno. V. 2. Edited by Filippi M, Bosak P. Czech Speleological Society. Praha. P. 147-152. 